\title{
Crimen y exhibición de prostitutas en el norte de Chile. Producción y uso de las imágenes del cuerpo de mujeres asesinadas
}

\section{Crime and Exhibition of Prostitutes in Northern Chile. Image Production and Use of Murdered Women Bodies}

\author{
Lilith Kraushaar \\ Universidad Católica del Norte, Chile \\ lilithkraushaar@gmail.com
}

\section{Resumen:}

Las clasificaciones de ciertos cuerpos, específicamente aquí el de "la prostituta" en momentos históricos específicos, nos plantean interrogantes sobre los imaginarios y las significaciones que las constituyeron, y los mecanismos que se utilizaron para lograr la distinción de estos cuerpos prostitucionales. Desde estos cuestionamientos analizamos algunas imágenes mediáticas de dos casos policiales de mujeres asesinadas: "La mujer de botas negras" en Calama de 1969 y "la mujer fondeada" en Antofagasta de 1983, en el norte de Chile. Su exposición y debate evidenció la convergencia de discursos de sexualidad, violencia y deseo de las relaciones de género y clase en la figura de "la prostituta" y su posterior influencia en la resignificación de estas mujeres como santas populares en esas ciudades mineras.

Palabras clave: fotografías, crímenes de mujeres, norte de Chile, prostitución.

\begin{abstract}
:
The classifications of the prostitute bodies by exclusion's operations, in specific historical moments, question the imaginary and the meanings of these classifications, and the mechanisms used to distinguish the prostitutional body. We analyzed here some media pictures of two police cases of murdered women: "the woman of black boots" of Calama in 1969 and "the sunken woman" of Antofagasta in 1983, both in Northern Chile. The public exhibition of these bodies show the convergence of speeches of sexuality, violence and desire, the gender and class relations inscribed on the "prostitute" figure, and the re-signification of these women as popular saints in those mining cities.
\end{abstract}

Keywords: Pictures, Murdered Women, North of Chile, Prostitution. 
... ella era una mujer de la vida fácil que un taxista la contrato y la mato vilmente... le saco los pechos cuando estaba viva y la descuartizó tirando sus pedazos por todas partes... ${ }^{2}$.

...he escuchado de chico de su historia, todos los calameños la saben, ella era una niña del ambiente... dos clientes la contrataron y la violaron primero y luego la mataron posiblemente porque ellos querían con los dos y otra petición, y luego se supo que la habían encontrado muerta camino a Chuqui...3.

.... a ella la mataron feo, que trabajaba en la sala de cerveza...y que los asesinos nunca la habían pillado, que los bestias le habían comido los pechos, la cabeza y que por eso no la reconocieron (...) y la canción que le hicieron había sido por el impacto que había causado el caso de botita ${ }^{4}$.

... a ella la acallaron de algo que sabía de la mafía de la coca, la acallaron, la fondearon..., ella trabajaba en el barrio rojo y aquí encontraron su cuerpo, ella era de Valparaíso y se había venido a trabajar a Antofagasta... ${ }^{5}$.

...ella era una mujer modelo que trabajaba en la bohemia, en la calle Bellavista, y la mato la mafia de la cocaína, la fondearon en el mar con un riel de trenes..., su cuerpo apareció inflado como un lobo marino... ${ }^{6}$.

... esta era chucheta, y corría mucha droga... y que no cabía duda que habían sido los detectives que la habían matado a golpes..que ya cuando la entraron al puerto ya estaba machucada y la habían vestido de hombre y la drogaron, venía mal, en la autopsia ya sabian que el tipo de golpe era de alguien que sabía, y ya estaba molida por dentro y eso solo lo saben hacer los detectives...?

1 El presente artículo está basado en distintos tipos de registros, principalmente en entrevistas y artículos de prensa. En las notas al pie de página se entregarán las referencias específicas de éstos, como por ejemplo, la información relativa a los periódicos. Luego, en la sección de referencias, se seguirá con el detalle de los libros y otras referencias tradicionales, para facilitar el uso de éstas al lector.

2 Entrevista a dos mujeres adultas mayores. Altar de Botitas Negras, Cementerio Municipal, 04-08-2010. Calama, Chile. Medio digital.

3 Entrevista a hombre mediana edad. Altar de Botitas Negras, Cementerio Municipal, 06-08-2010. Calama, Chile. Medio digital.

4 Entrevista a hombre adulto que trabaja en una radio de Calama. Altar de Botitas Negras, Cementerio Municipal, 12-08-2009. Calama, Chile. Medio digital.

5 Entrevista a pareja mediana edad. Altar de Juanita, Avenida Pérez Zucovich, 12-02-2011. Antofagasta, Chile. Medio digital.

6 Entrevista a pareja adulta con un niño menor. Altar de Juanita, Avenida Pérez Zucovich, 17-02-2011. Antofagasta, Chile. Medio digital.

7 Entrevista a mujer mediana edad. Altar de Juanita, Avenida Pérez Zucovich, 20-02-2011. Antofagasta, Chile. Medio digital. 
"Botitas Negras" en Calama y “Juanita" en Antofagasta son conocidas figuras religiosopopulares. En sus altares, visitantes y devotos relatan historias describiéndolas con características comunes y destacando la violencia de los crímenes que sufrieron, la impunidad de sus asesinos y su pasado de prostitutas. Estas referencias fueron expuestas y debatidas en la prensa de esos años, 1969 y 1983 respectivamente. Hoy forman parte de las historias que se cuentan de estas mujeres/figuras. De ahí nace nuestro interés en analizar y comparar las imágenes y descripciones de ambos asesinatos publicadas en la prensa del norte de Chile: "La mujer de botas negras" y "La mujer fondeada", nombres utilizados por la policía y la prensa como recursos para involucrar a la población en la construcción de significantes femeninos sexualizados de violencia que aún forman parte de los imaginarios de la población. ¿Cómo hacen los agentes de estado para darle usos y significados a las imágenes de los cadáveres informes de mujeres asesinadas en distintos momentos históricos? Para responder parte de esta pregunta, nos proponemos una aproximación al análisis de las disposiciones y la función de las imágenes para figurar una puesta en escena eficaz para la reafirmación y sanción de ciertas normas e ideologías sexuales, de género y clase, en estructuras histórico-políticas específicas.

\section{La exposición de las imágenes y su contexto}

La indagación policial de los asesinatos tuvo una amplia cobertura mediática que nos permitió conocer las representaciones y el interés paradojal de los discursos de agentes de Estado (jefes de policías, alcaldes, obispo, etc.) al exponer la prostitución como "madre de todos los problemas" y, al mismo tiempo, como un “mal necesario”. Ambos discursos luego serán usados para justificar acciones de intervención policial en lugares y grupos señalados como "marginales" con el objetivo de restablecer el "orden” e higienizar los lugares públicos de la proliferación "del mal” y la "enfermedad” asociada a la prostitución?", así proporcionar un "mejor servicio a la 'clientela' del gran contingente masculino que 'necesita satisfacer sus necesidades biológicas"'10 en estas ciudades mineras.

En 1969, Calama se caracterizaba por su rápido crecimiento poblacional debido a la alta inmigración (Bähr 7) producida por las oportunidades laborales de la industria minera ofrecidas en ese entonces por la compañía norteamericana Chile Explotation Company. El

8 Para mayor referencia sobre el caso y la devoción popular de Botitas Negras véase el artículo de Jorge Pavez y Lilith Kraushaar, "Nombre, muerte y santificación de una prostituta. Escritura y culto de Botitas Negras", AIBR Revista de Antropología Iberoamericana 5 (3): 447-492, 2010.

9 Ver: "Notable índice de aumento de criminalidad en El Loa". El Mercurio de Calama, 30 de noviembre 1969: portada [Calama, Chile]. Medio impreso; "Poca atención de autoridades nacionales estanca el progreso en Calama". El Mercurio de Calama, 30 de diciembre 1969: portada [Calama, Chile]. Medio impreso; "En Calama también buscan la pista de La Mujer Fondeada". "La occisa podría ser tocopillana”. La Estrella del Norte, 24 de febrero 1983: 6 [Antofagasta, Chile]. Medio impreso.

10 Ver: "Proxenetas se oponen a la erradicación de lenocinios". El Mercurio de Calama, 6 de enero de 1970: portada [Calama, Chile]. Medio impreso; "Villa lenocinio: una aberración”. El Mercurio de Calama, 6 de enero 1970: 4 [Calama, Chile]. Medio impreso. 
llamado de la compañía era a los "jóvenes con alguna o ninguna calificación y con familia pequeña" (Manning 92) para constituir una fuerza de trabajo permanente que viviera en el campamento. De la mayoría de los hombres contratados, se esperaba también por parte del gobierno local y nacional que contribuyeran con su trabajo al denominado "desarroIlo" económico de la ciudad y del país: "La recia estampa del minero. Sobre sus fuertes hombros pesa la explotación de la riqueza cuprífera del país. Firme y arrogante, desafía el abrasador sol del desierto y el penetrante frío de la noche pampina" (Alvear 13). Pero este llamado no consideraba a la otra gran mayoría de hombres y mujeres que esperaban en la ciudad una oportunidad laboral, considerados los "otros" migrantes: "prostitutas", "delincuentes", "caza fortunas", "niños delincuentes” y el "tercer sexo" eran una amenaza porque acarreaban con ellos una "vida licenciosa”, delincuencia, enfermedades, "comercio clandestino", "consumo excesivo de alcoholes"11, desintegración de "la familia”, "desnudo" y perversión de la juventud ${ }^{12}$.

En sus discursos, jueces, policías y periodistas consideraban que "las exuberantes remuneraciones de la gran minería” tentaban únicamente a prostitutas, hampones y delincuentes $^{13}$. Particularmente vulnerables a esta tentación serían, según estas autoridades, las mujeres migrantes solteras con baja o ninguna formación educacional, ya que se veían obligadas a "conformarse con un trabajo de bajo nivel social" (principalmente en labores domésticas) y luego "se encandilan con el dinero y encuentran amistades no muy convenientes que inculcan el trabajo fácil" ${ }^{14}$. Estas mujeres que se "entregaban" a la prostitución, por la atracción del dinero que producía "el trabajo minero", eran presas de este discurso vicioso que, por un lado, buscaba generar temor al señalarlas, a ellas, a sus hijos, como "delincuentes" y a sus parejas como "lachos" o explotadores que viven a sus expensas ${ }^{15}$. Por otro lado, se intentaba garantizar su servicio a la clientela erotizando su figura porque estas estarían "dispuestas a complacer todos los vicios" ${ }^{16}$.

11 "Preocupan infructuosas pesquisas en torno al homicidio de Irene Iturra S.". El Mercurio de Calama, 28 de septiembre, 1969: portada [Calama, Chile]. Medio impreso; “Poca atención de autoridades nacionales estanca el progreso en Calama”. El Mercurio de Calama, 30 de diciembre 1969: portada [Calama, Chile]. Medio impreso.

12 Ver: "Sexualidad juvenil al desnudo. Profesora de la U. del Norte analiza la explosión erótica. Nuestra sociedad glorifica el sexo”. La Estrella del Norte, 23 de octubre 1969: portada y 3 [Antofagasta, Chile]. Medio impreso; "El afán de desnudarse en la mujer puede compararse al empeño vanidoso del hombre por sobresalir en algún tipo de negocio o deporte". La Estrella del Norte, 11 de octubre 1969: 4 Suplemento sábado [Antofagasta, Chile]. Medio impreso; "Detienen a huanchaqueros por lucirse en minifalda". La Estrella del Norte, 31 de octubre 1969: 16 [Antofagasta, Chile]. Medio impreso; “Dime cuanto mide tu mini y te diré de donde eres”. La Estrella del Norte, 1 de octubre 1969: 13 [Antofagasta, Chile]. Medio impreso; “El lenguaje de las piernas". La Estrella del Norte, 4 de octubre 1969: 4 [Antofagasta, Chile]. Medio impreso; “discotecas no son buates". La Estrella del Norte, 9 de octubre 1969: 13 [Antofagasta, Chile]. Medio impreso; “ihay que envidiar o compadecer a la mujer soltera?. La Estrella del Norte, 18 de diciembre 1969: 13 [Antofagasta, Chile]. Medio impreso.

13 "Notable índice de aumento de criminalidad en El Loa". El Mercurio de Calama, 30 de noviembre 1969: portada [Calama, Chile]. Medio impreso.

14 "Poca atención de autoridades nacionales estanca el progreso en Calama". El Mercurio de Calama, 30 de diciembre 1969: portada [Calama, Chile]. Medio impreso.

15 "Proxenetas se oponen a la erradicación de lenocinios". El Mercurio de Calama, 6 de enero 1970: portada [Calama, Chile]. Medio impreso.

16 "Las alegres noches y ...sus lacras". El Mercurio de Calama, 4 de noviembre 1971: 2 [Calama, Chile]. Medio impreso. 
Al igual que el resto del país, Antofagasta, en 1983, se encontraba en plena dictadura militar con un violento control policial y una fuerte influencia moralista de la Iglesia católica. En su constante desviación de la atención de conflictos sociales, atropellos, abusos y crímenes, la crónica roja y el espectáculo revisteril se utilizaban ampliamente como distractores. Esta forma de distracción se hizo particularmente evidente después de la crisis económica de 1982 con el escándalo de la quiebra de los bancos y las altas tasas de desempleo. La ciudad puerto del mineral cuprífero, no exenta de la crisis y de la cesantía, ni tampoco de la influencia capitalina de la fantasía bohemia de los espectáculos revisteriles, era fuertemente controlada por policías y detectives y a la vez señalada por el asecho de la delincuencia y del tráfico de cocaína. Ante cualquier acontecimiento extraño de violencia o muerte, la policía y la prensa lo asociaban a la llamada "gente de la noche": a los que se "atreven a salir en la noche"17 (en relación al toque de queda), a los que se trasforman en pervertidos, a "clientes insaciables", a los "traficantes homosexuales", todos con "horizontes sexuales indefinidos"18 que les "permiten liberar los más ocultos y escondidos instintos sexuales"19. Lo que propiciaba un clima de inestabilidad, miedo y sospecha, en el que nadie quería verse "involucrado" con nadie y era preferible "no hablar" para no ser señalado. En este clima se idealizaba a la familia como espacio de participación. Según Kemy Oyarzún, esto se puede entender como el "ideologema de la familia" porque se expresa la relación del espacio social a una relación exclusiva con el Estado-pater y en su sola capacidad de "asimilar a su espacio prácticas discursivas provenientes de lo político (el Estado) y lo religioso (en el caso chileno, la iglesia católica)" (274), lo que generaba una fuerte estigmatización hacia las mujeres que migraban a otras ciudades y abandonan "el hogar", sindicadas como "mujeres de la calle", "mujercitas que se mueven de un lado a otro"20, e inexorablemente asociadas a las mujeres que "alegran las noches de los hombres con sus bailes y desnudos" 21.

Estos discursos e imágenes publicados a propósito de los asesinatos de estas mujeres, no hicieron otra cosa que revelar el conflicto de clase, raza y violencia de género que ya estaba presente entre los grupos de migrantes que llegaban a "probar suerte" o "buscar trabajo" en estas ciudades mineras. Y es precisamente a partir de la lectura de estas operaciones de inclusión-exclusiva de ciertos grupos, develada en la indagatoria de esto s crímenes, que se activaron procesos de resignificación por parte de las personas que se consideraban cercanas, afines y solidarias hacia estas mujeres asesinadas, en cuanto a lo que se podía hacer y decir sobre estos cadáveres.

17 “iPor fin se sabe quien es!. Confirmado La fondearon viva”. La Estrella del Norte, 25 de febrero 1983: portada [Antofagasta, Chile]. Medio impreso.

18 "Apasionantes entretelones entorno al hallazgo del cadáver. Revelador testimonio de testigos claves". La Estrella del Norte, 23 de febrero 1983: 6 [Antofagasta, Chile]. Medio impreso.

19 "Apasionantes entretelones en la vida de la mujer Fondeada. Una historia controvertida". La Estrella del Norte, 26 de febrero 1983: última página [Antofagasta, Chile]. Medio impreso.

20 "Cerco de hermetismo rodea caso de la Mujer Fondeada". "¿crimen o suicidio?, ¿quién es la mujer fondeada?, en qué lugar de la segunda región desapareció una mujer, una madre, tal vez una esposa?, porque nadie se presento a reclamar el cuerpo..?, se lanzó al mar? Fue arrojada por manos asesinas?. La Estrella del Norte, 24 de febrero 1983: 5 [Antofagasta, Chile]. Medio impreso.

21 "En Calama También buscan la pista de La Mujer Fondeada". La Estrella de/ Norte, 24 de febrero 1983: 6 [Antofagasta, Chile]. Medio impreso. 
Las técnicas de registro-inscripción que se utilizaron para identificar y clasificar estos cadáveres sirvieron como instrumentos para definir y organizar el lugar de los significantes para agentes de policías y periodistas. Estos mismos instrumentos luego serían reempleados o se "vale de" estos (Certeau 36) para resignificar a estas figuras de prostitutas asesinadas como milagrosas en distintos momentos históricos. A partir de ahí se podría decir que a estas mujeres/figuras se les confiere un valor de uso e intercambio que se actualiza del momento histórico político que las produjo y que se va a potenciar en las distintas prácticas y grupos que continúan resignificándolas en sus altares, especialmente por el papel que se le asigna a la figura de "la prostituta" en la organización y estructura social de estos enclaves productivos del capitalismo industrial.

\section{Las técnicas de registro y la construcción de significados en las imágenes de los cadáveres de "la mujer de botas negras" y "la mujer fondeada"}

La pregunta sobre la construcción de significantes y significados a partir de las imágenes de estos cadáveres de mujeres implica para nosotros referirnos a las técnicas y acciones que se utilizaron para la producción de un cuerpo biopolítico que, de acuerdo a Agamben, se presenta en el cruce entre "técnicas de individuación y procedimientos totalizantes"(16), en la esfera del poder soberano que en su grado de aparente legitimación las emplea en procesos de "exclusión inclusiva" los cuales exploraremos aquí en función de imágenes utilizadas para identificar, clasificar y registrar a estas mujeres asesinadas.

\section{La mujer de botas negras}

El empleo y la selección de imágenes presentadas lo entendemos como un intento de descifrar lo que no se sabe aún pero que se da por conocido, y lo que se pone a prueba exponiéndose como indicio con el afán de producir efectos o generar hechos. La fotografía del cadáver de la mujer encontrada en los faldeos de la sierra de Montecristo, camino de Calama a Chuquicamata, fue publicada una sola vez y luego prohibida su reproducción por mandato del juez a cargo porque entorpecía las investigaciones que se llevaban a cabo. Este hecho estimuló aún más el misterio y el secreto de su identidad y la de sus asesinos, volviendo una y otra vez la atención constante en la prensa a la descripción escrita de los detalles sobre la condición y violencia ejercida en contra del cadáver. La inscripción de estos detalles del cadáver mostraban una proyección fantasma de la fotografía en el lugar del hallazgo donde yacía Irene Iturra, en la que se enfatizaba, por un lado, cada vez más los recortes del cuerpo o la falta de órganos, de los pechos, del cuero cabelludo, de la mutilación de dedos. Y por otro lado, lo que quedaba o el resto, un vestido roto, calzones machados con sangre, un por- 


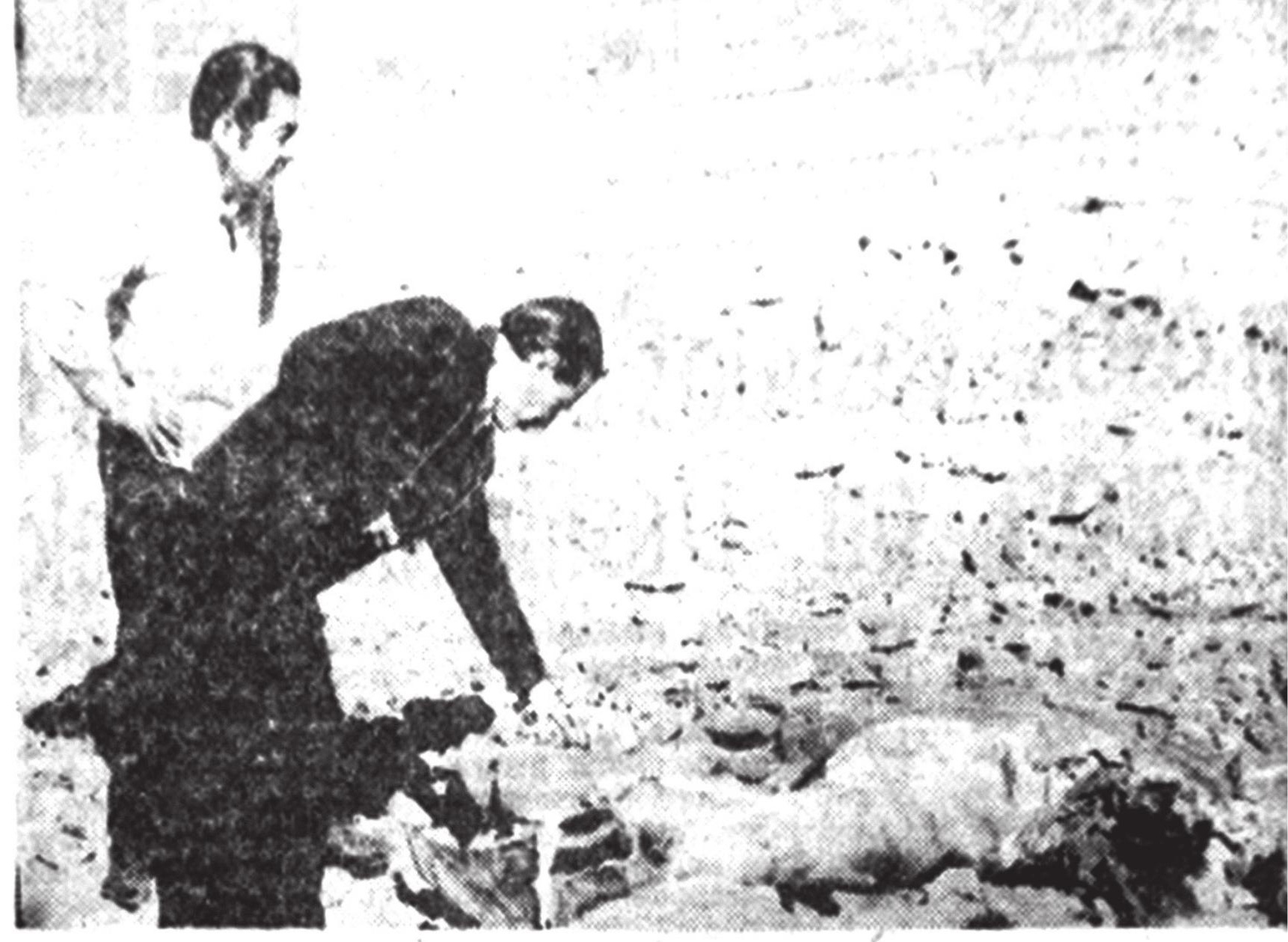

El Magistrado del Primer Juzgado del Crimen de Calama, señor Re Villegas, observa el cadáver, cuyo rostro está desfigurado, al parec acción de zorros y pericotes, que abun dan en el lugar. Lo acompo de Investigaciones de Chuquicamata, señor Luis Aceituno

\section{Aún no identifican cadáver de $n$ asesinada cerca de Chuquica}

Activas diligencias realiza la policia civil de El Loa paa identificar a la mujer aseinada a 15 kilometros de Chuquicamata y en busca de os autores del bárbaro hoajeidio que ha tenido reperusión nacional al ocupar en randes tituiares las primeras aginas de muchos rotativos la zona central. rado a la población. Es ast como las pesquisas se han efectuado con gran amplitud en todos los centros de diversion nocturnos, en especial en los lenocinios del centro y de sectores apartados de $\mathrm{Ca}$ lama. Se han efectuado numerosos interrogatorios entre los que viven o trabajan en esos negocios.

Según noticias extraoficia-
De acuerdo eo mes, en el lugs se descubrieron vehículo peque! sos rastros de permitiria prest individuos acos autor del homi

En fuentos cas se adelanti cldio Tlene 


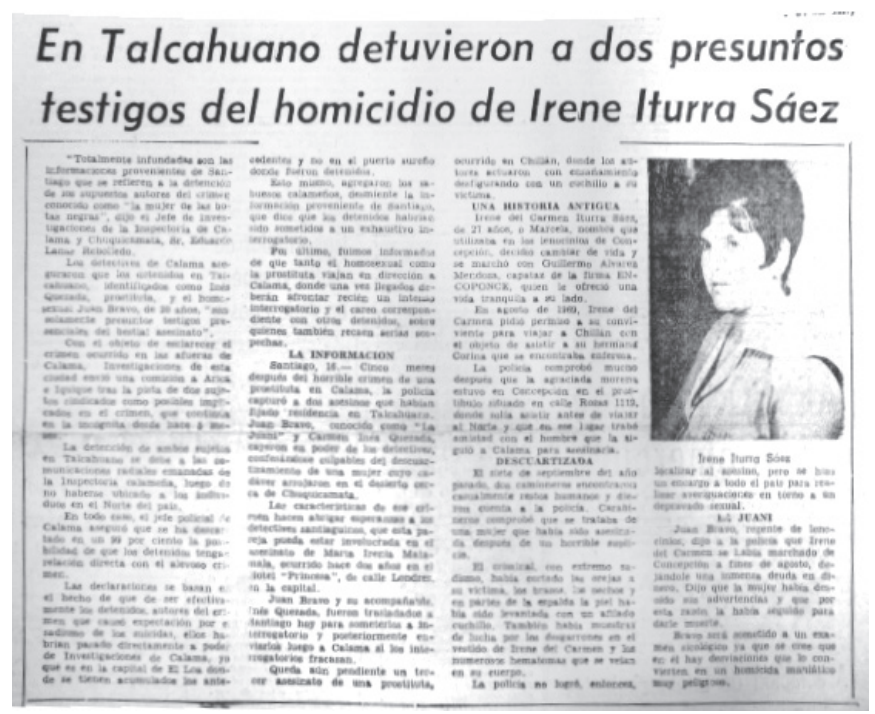

Figura 2.

taligas negro y las botas negras. Las botas negras se transformaron en ese resto que quedó y la única cosa inanimada que cobró vida humana para identificar el cadáver (ver Figura 1):

El Personal de investigaciones se trasladó al lugar del hallazgo, estableciendo que el cadáver corresponde a una mujer entre 20 a 30 años, y de 1.65 mt. de estatura, al que le faltaban los pechos y todo el cuero cabelludo, nervios y piel de la cara y orejas, así mismo la mano piel y tendones del brazo y antebrazo izquierdo, todo lo cual habría sido comido por zorros. El cadáver estaba con un vestido de algodón floreado café con fondo amarillo, levantado hasta la altura del pecho, botas negras con cierre eclair, una cintado, media y calzón bajado a la altura de las tibias. Se encontraron otras prendas como portaligas negros, anillo sin inscripción y tirantes de sostén-senos, más un sujetador de pelo roto. En el lugar donde quedó apoyada la cabeza hay charcos de sangre por escurrimiento. Las heridas y fracturas al cráneo serían de reacción post morten pero los hematomas del vientre y piernas son de reacción vital. La mujer murió a causa de lesiones y fracturas múltiples del cráneo con salida de masa encefálica y anemia aguda [...]. Según noticias no confirmadas la policía del mineral encontró cerca del cadáver una herramienta envuelta en sacos y papeles, en cuyo mango hay pelos adheridos y sangre seca. Ello explicaría las huellas evidentes de que la mujer fue bárbaramente golpeada con objetos contundente ${ }^{22}$.

22 “Atroz crimen en Chuqui”. Estrella del Norte, 8 de septiembre, 1969: portada [Calama, Chile]. Medio impreso. 
La descripción escrita del cadáver se asimila a la aproximación que hace André Menard en su análisis de la fotografía etnográfica y la pornografía actual, en cuanto a su dimensión "funcional y formal". En su dimensión funcional "se trata de una producción orientada más a la producción de un efecto (excitación sexual) que a la narración de una historia o a la instalación de unos nombres propios (de los personajes, de los actores, del director)", y , en su dimensión formal "como la puesta en escena de un funcionamiento. Y esto mediante el uso preferente del close-up y de la presentación del cuerpo como un lugar fragmentado" (17). El uso del encuadramiento o del close-up pornográfico amplia las imágenes inscritas del cadáver de Irene en una disección escritural que reflejaba su condición de despojo a partir del hallazgo y culminan con la posibilidad de reunir las partes en su antiguo cuerpo. Este solo vuelve a ser una totalidad en la proyección del imaginario de los devotos que la transforman en una figura sagrada espectral.

La proliferación de imágenes de las partes del cuerpo y de los restos de órganos y ropas funcionan aquí por contraste como "operador moral" para codificar esta producción de imágenes en las notas de prensa, a las que luego se le fueron agregando calificativos que se focalizaban en armar una historia que suponía la vulnerabilidad de la mujer y la monstruosidad del asesino (ver Figura 3, 4 y 5):

Cautelosamente se ha estado siguiendo una pista entre las relaciones que tenía la víctima y las actividades realizadas hasta la fecha del crimen, el 20 de agosto al medio día en que desapareció de su domicilio. Sombras del pasado que la torturaban los últimos días de la infortunada joven, que había llevado una vida licenciosa en Concepción. Varios testigos han podido comprobar los últimos contactos de Irene Iturra con dos hombres y una mujer aproximadamente de 50 años, el mismo día que se presume ocurrió el asesinato. La joven concurrió a ese día poco después de las 12 horas a una cita, engañada.

Muchos entrevistados por este diario que tenían cierta amistad con Irene del Carmen, han manifestado indignación por la impunidad de que aún goza el asesino, pues la víctima era muy generosa. Se observa cierta preocupación en el Departamento por las infructuosas diligencias de la policía entorno al caso pese a que los días pasan vertiginosamente y el tiempo desvanece las pistas una tras otra. Se espera con expectación el arresto del feroz homicida, para quien se desea el pelotón de fusilamiento por haber cometido un crimen premeditado en despoblado en la persona de una débil mujer burdamente engañada ${ }^{23}$.

El criminal, con extrema sadismo, había cortado las orejas a su víctima, los brazos, los pechos y en partes de la espalda la piel había sido levantada con un afilado cuchillo. También habían muestras de lucha por los desgarrones en el vestido de Irene del Carmen y los numerosos hematomas que se veían en el cuerpo ${ }^{24}$.

23 "Preocupan infructuosas pesquisas en torno al homicidio de Irene Iturra S.". El Mercurio de Calama, 28 de septiembre 1969: portada [Calama, Chile]. Medio impreso. El énfasis en cursivas es mío.

24 "En Talcahuano detuvieron a dos presuntos testigos del homicidio de Irene Iturra Sáez.". El Mercurio de Calama 17 de enero 1970: portada [Calama, Chile]. Medio impreso. El énfasis en cursivas es mío. 

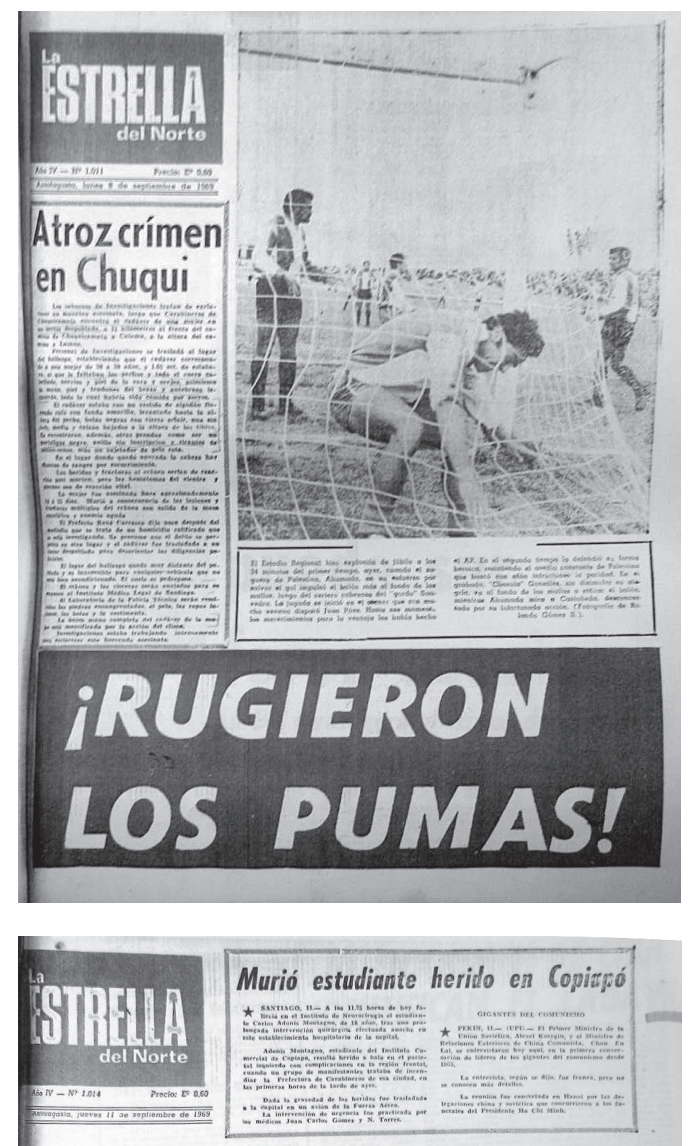

Irene Iturra, víctima del chacal de Chugui

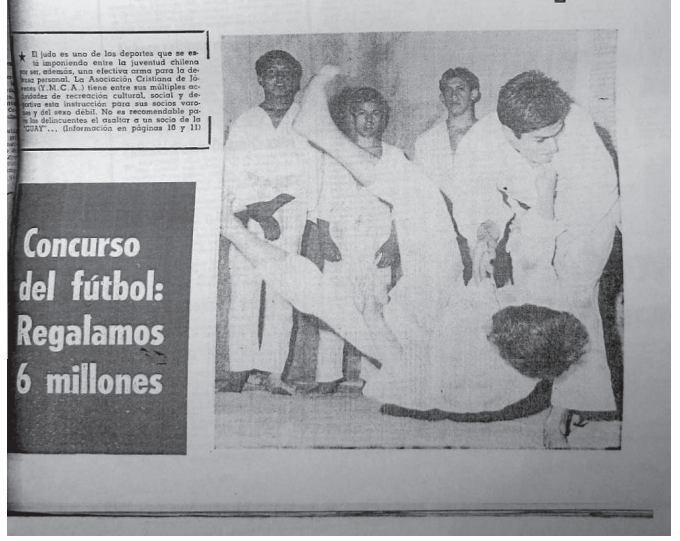

Figura 3 y 4. 


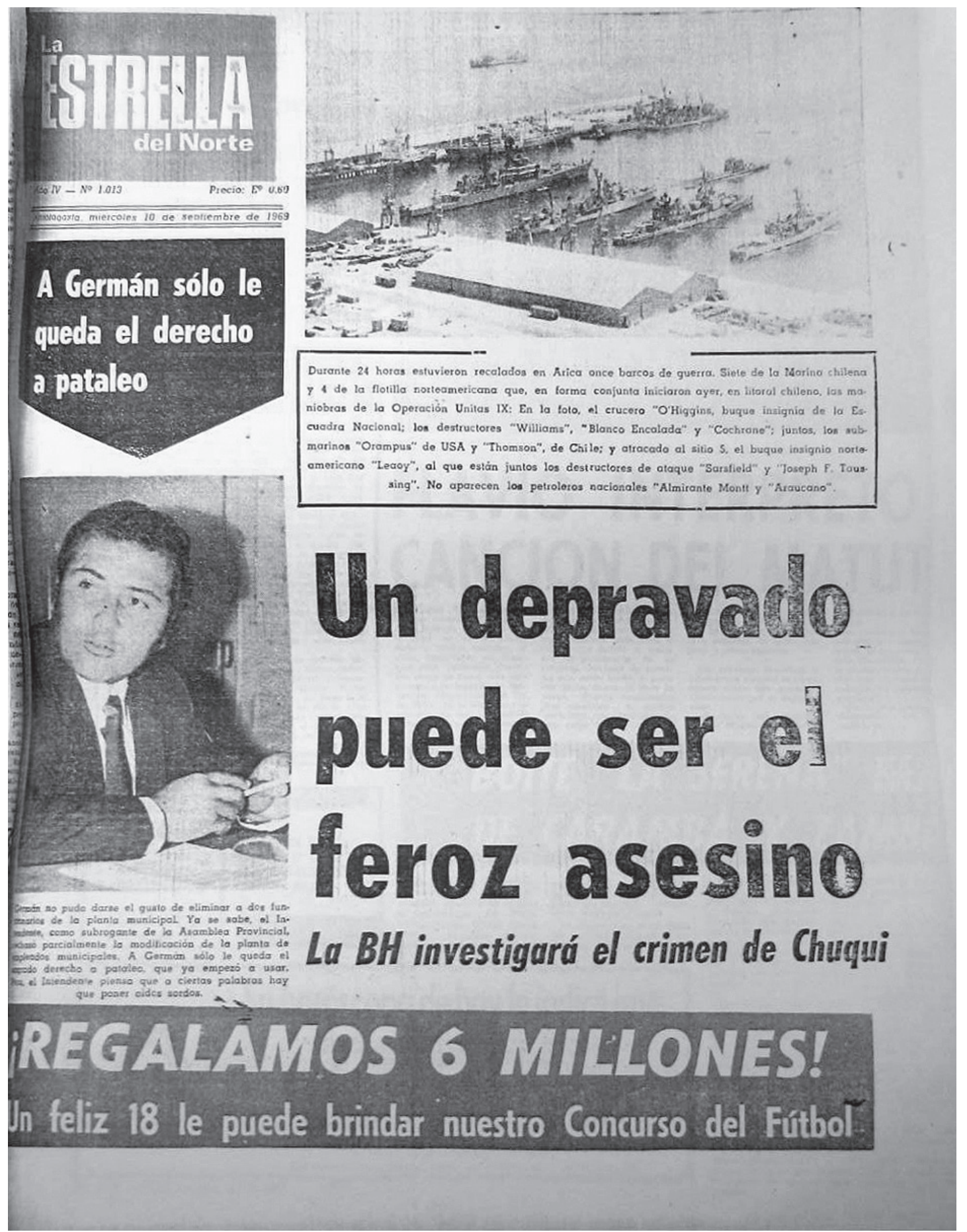

Figura 5. 


\section{Fondearon a una mujer en Antofagasta}
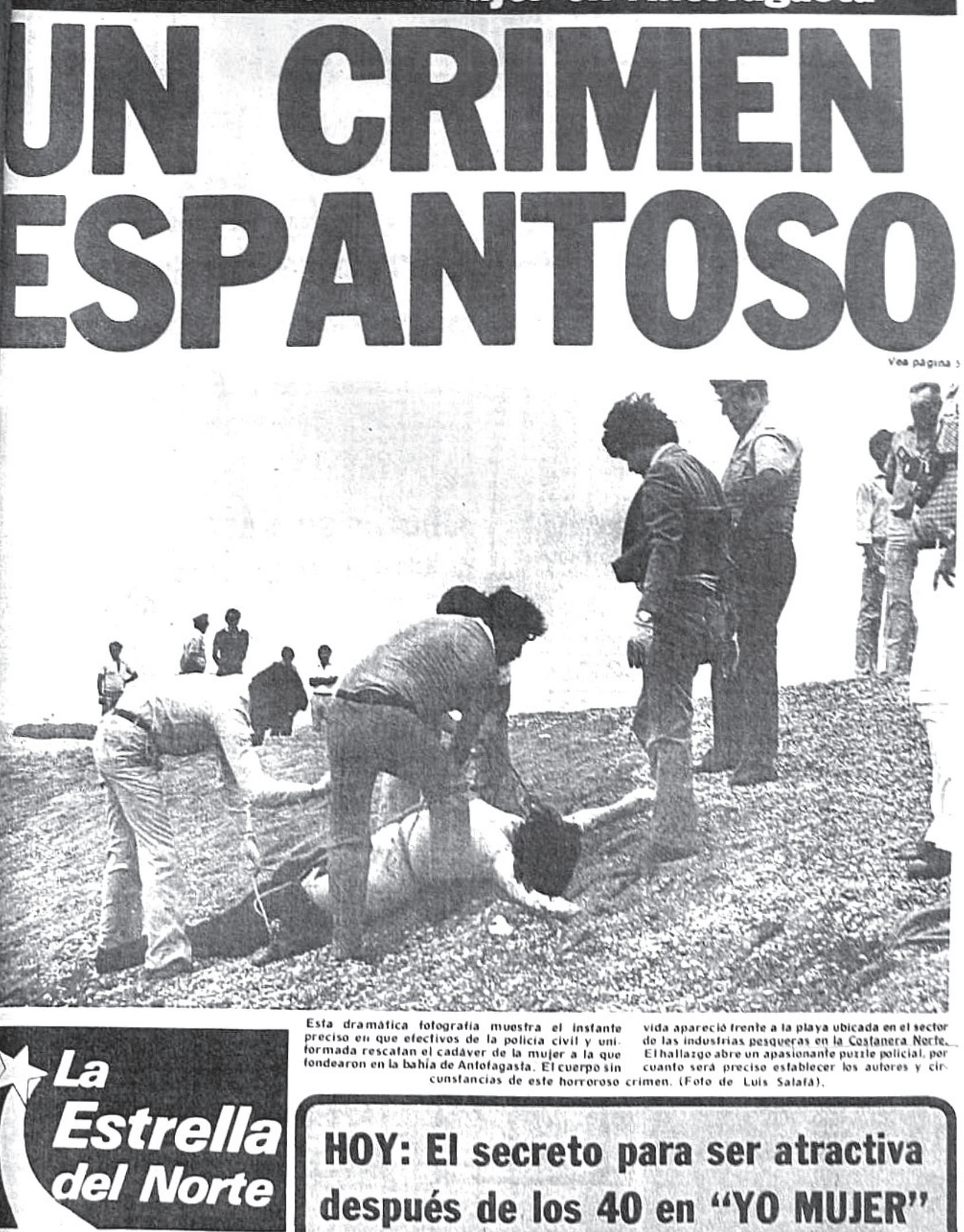

OXVII-N* 4,047 PRECIO (IVA incl.) \$15,00 Antolagasta, Martes 22 de lebrero de 1983
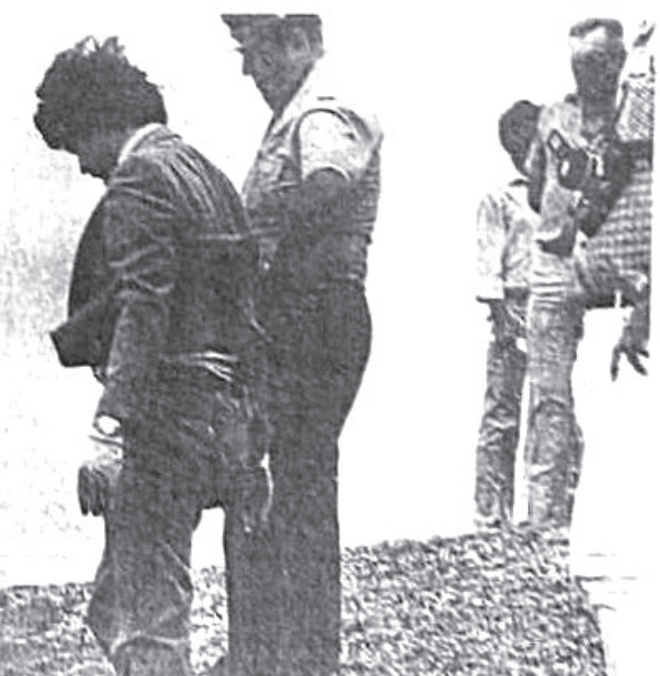
HOY: Apasionantes entretelones del caso que estremece a todo Chile
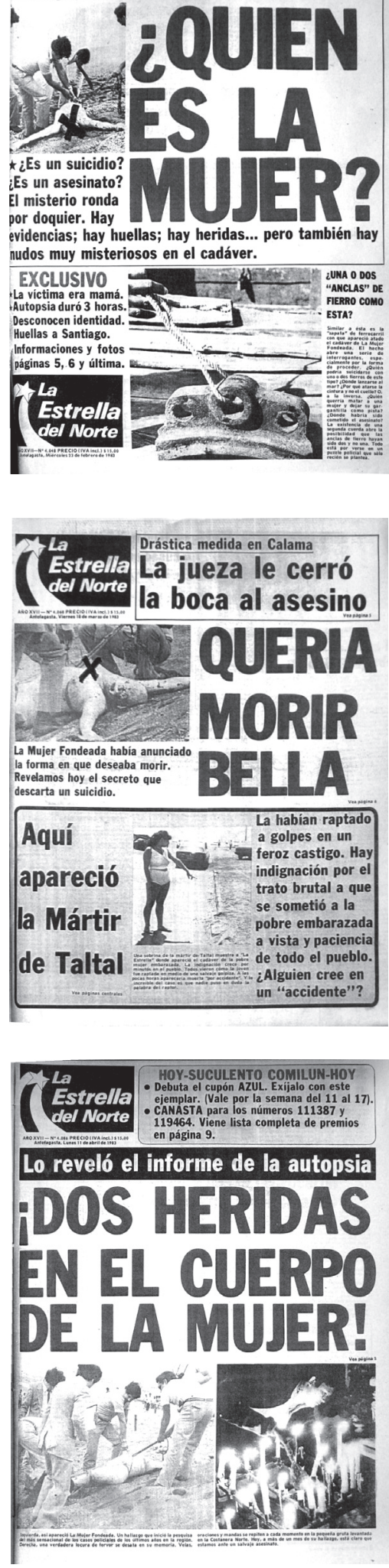
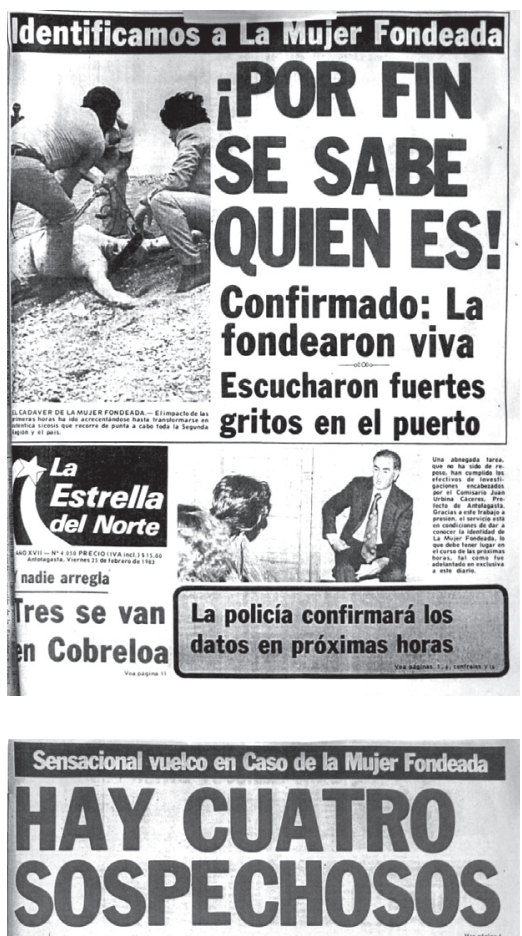

Definitivo: lanzaron a la víctima en un sitio profundo, donde había petróleo.- Estudian posible contaminación de drogas en sus vísceras.- Descartada la tesis de la violación.La posibilidad del suicidio se aleja cada vez más.
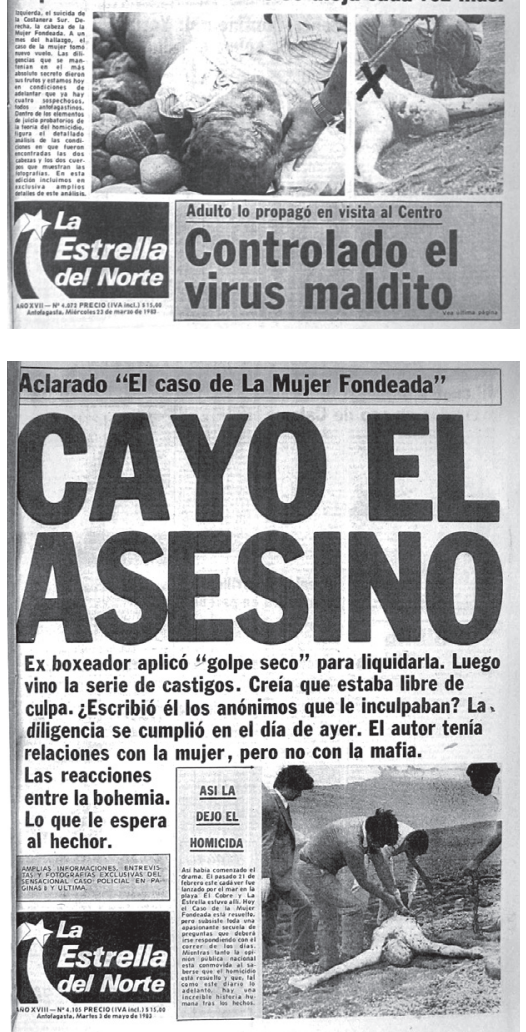

Figura 6 (izquierda) y Figuras 7, 8, 9, 10, 11, 12 y 13. 
La descripción de la fotografía del cadáver circuló alrededor de siete meses hasta que publicaron la falsa noticia en la prensa que habían encontrado a los culpables: "Resuelven Crimen de Irene Iturra S.”25 (ver Figura 2) lo que pausaba momentáneamente la presión sobre el caso policial. Sucesivamente, se entregaron algunas noticias hasta que en 1971 fue sobreseído el caso. Pero esto no detuvo las especulaciones sobre la resolución del caso y la identidad de los asesinos, ya que aparecieron historias y prácticas rituales por parte de los visitantes de sus tumbas. Es precisamente en estas historias donde siguen operando las inscripciones sobre la condición de su cadáver, el lugar donde la ocultaron y encontraron asesinada, y la monstruosidad de sus asesinos. Estas inscripciones configuran actualmente a Botitas Negras como santa popular en Calama.

La producción de imágenes escritas, la condición del cadáver, el lugar del hallazgo y la violencia de los asesinos, supone conocer "las competencias del lector" (Vilches 40) o las posibilidades de significación de estas por parte de policías y periodistas. De ahí que la asociación entre "vida nocturna", "prostitución” y “delincuencia” opere como transgresión y sean previsibles las consecuencias para aquellos "hombres solos que se atreven a salir de noche" y las mujeres que no se resguardan en sus casas. Este mensaje viene a legitimar y habilitar pericias policiales y periodísticas que se basan en una voluntad y dominio de “el saber en el acto de ver” y el “cómo se debe leer" (Didi-Huberman 87). En esta lógica presentacional, a través de la selección de fotografías, agentes policiales entregan el "valor de indicio" y el "cuerpo del delito" (50) que junto a informes policiales, autopsias, declaraciones, relatos sensacionalistas, historias de vida, confesiones, entrevistas de los medios de comunicación, actúan, según Judith Walkowitz, como motores y configuradores del pánico moral, sobre todo en su función de expresar el exceso, las repeticiones, los propósitos cambiantes y los subjetivismos, los "que ofrecen la materia prima, en forma de palabras e imágenes... a la proliferación de significados sociales y eróticos más oscuros...”(242).

\section{La mujer fondeada}

La selección de imágenes y su uso en el caso del asesinato de "la mujer de botas negras" se restringió casi a una sola fotografía, a diferencia, como veremos, de la multiplicación de las imágenes del cadáver encontrado en la playa "El Cobre" en Antofagasta, durante toda la cobertura de prensa del homicidio ${ }^{26}$. Las fotografías del hallazgo del cadáver se exhibieron

25 “Resuelven crimen de Irene Iturra S.". El Mercurio de Calama, 25 de enero 1970: portada [Calama, Chile]. Medio impreso.

26 En Calama se publicaron dos fotografías de Irene Iturra: un retrato de medio cuerpo en vida, y otra de su cadáver tal como fue encontrado. Estas se insertaron en seis portadas y noticias al interior del diario entre 1969 y 1971. De Juana Guajardo se publicaron 75 fotografías en 53 portadas, sin contar las fotografías de parientes, amigos, amantes, lectores, policías, y abogados que fueron consultados acerca del crimen. Esta diferencia no radica en lo controversial de los casos para cada época, sino en que, en el caso de Juana, los cambios de discursos y declaraciones acerca de las causas de su muerte y el uso que se hizo de ésta como "cortina de humo", fueron variando con el fin de invisibilizar el tráfico de cocaína y sus involucrados por parte de la policía. Lo que requirió varias historias diferentes acerca de su vida y muerte en un contexto de control de la dictadura militar. 
de distintos ángulos y distancias en la playa, y en todas las imágenes aparecen hombres (policías) manipulando el cadáver desnudo atado a las cuerdas que aún lo envolvían y que tenían en uno de sus extremos unido el freno de tren que fue utilizado como ancla para hundirlo (Ver de la Figura 6 a la Figura 12). El mensaje que se puede leer aquí se dirigía al hacerse cargo, a la apropiación y a la organización paternalista no solo del cadáver sino de las consecuencias de los comportamientos desviados en el momento justo antes de que estallen las especulaciones que mostraban el permanente estado de excepción en que se vivía. Y una de las maneras en que se mostraba ese estado era normalizando el hecho de muerte por suicidio o por asesinato como enfermedad sicológica, especialmente en las mujeres que incurrían en estos actos por su propia inestabilidad emocional o por ser víctimas de una pareja aquejada por los celos. Finalmente en este discurso lo que parecía llevar a estas mujeres por esta vía "fatal” y desencadenaba hechos de violencia, era la falta o la negación de una familia:

Una forma violenta de morir. La policía civil considera que el caso de la "mujer fondeada" tiene características de suicido, "sin embargo ante anteriores suicidios de mujeres registrados en esta ciudad, en condiciones muy similares, éste caso tiene un hecho de violencia que lo transforma en un hecho nuevo para los antofagastinos. El "Caso de la mujer de Roca Roja" que conmovió también a la opinión pública, por las condiciones que apareció flotando en las aguas del sector sur de ésta ciudad, no hizo descartar de inmediato la intervención de terceras personas, si embargo no existía otro elemento que obligara la muerte por inmersión, como ocurrió en este caso. La falta de familiares que denunciaran la desaparición de la suicida, como también el oportuno reclamo de los restos mortales en el Servicio de Patología en el hospital local, pusieron la nota de suspenso, para conocer las verdaderas razones de la trágica determinación.

La autopsia revela la acción suicida. La verdad (suicidio) sólo la revelará la autopsia. ¿Violencia Femenina?, Se describen los patrones de suicidio femenino "la violencia es uno de los caminos menos recorridos, lo que contrasta con la de los varones, que resultan macabras y sobrecogedoras como en los suicidios conocidos como "la muerte del minero", entre otros. Rara vez una mujer decide poner termino a sus días, colgándose de una soga y disparándose un tiro. La elección se inclina por los tranquilizantes y con menos frecuencia se cortan las venas y se arrojan al mar. De los suicidios registrados en el litoral de antofagastino, éste parece ser el de mayor violencia, ya que la desesperación propia de un ser humano al enfrentarse a la muerte, le obliga a tratar de defenderse hasta las últimas consecuencias" ${ }^{27}$.

Las fotografías del cadáver de Juana Guajardo se exhibieron casi todos los días en la edición del diario la Estrella del Norte de Antofagasta desde que fue hallado su cadáver en febrero hasta julio de 1983. Estas fotografías del cadáver en la playa fueron expuestas junto a otras fotografías de ella, de periodistas, de sospechosos, de prácticas rituales

27 “Una forma violenta de morir". La Estrella del Norte, 23 de febrero 1983: 5 [Antofagasta, Chile]. Medio impreso. 
para comunicarse con muertos y de su propia animita. En una especie de develamiento por etapas de su identidad, las fotografías que se publicaban eran de distintos ángulos y posiciones del camarógrafo y de los acomodos que se le hacían al cadáver (con pantalones y sin ellos), como en un recordatorio constante de la violencia y del destino final de esta mujer (Ver de la Figura 6 a la 13). En las variaciones de aperturas del lente fotográfico y de los close-up prevalecían las marcas de lápiz y las partes descubiertas en un afán de destacar, manipular y censurar al lector ciertas partes del cadáver que darían cuenta de su identidad o de sus asesinos.

Especialmente las fotografías de su rostro fueron apareciendo lentamente y particularmente encuadradas hasta mostrarse en primer plano. En un principio se tachó el rostro con una cruz; luego, la marca fue desapareciendo en las siguientes publicaciones, hasta dejar un rostro irreconocible al descubierto (Ver de la Figura 6 a la Figura 11), como si se quisiera dejar para el final aquello que no se puede conocer antes de establecer el "cómo se debe leer" o para lograr el impacto del rostro-monstruo que sostiene la paradoja macabra de la muerte de una mujer que se describía por su belleza (ver Figura 9).

Las marcas de lápiz pretenden ganar tiempo al ir dando a conocer, al mostrar y ocultar lo que no se conoce, al exhibir lentamente este cadáver informe para que vaya abriendo posibilidades de generar imaginarios e información de manera que pudiera ser manejado o controlado lo que no se sabía de la mujer. Específicamente, fue la marca de cruz de lápiz en su pecho que cubría una gargantilla colgada aún a su cuello, considerada pieza clave para develar su identidad, la que fue reconocida por colegas de Juana, pero el control sobre su identidad se mantuvo con la justificación de que se esperaban también las pruebas de laboratorio. Pruebas que no entregaban o distorsionaban resultados acerca de su identidad, de la forma de morir, y de los asesinos:

Antofagasta. El mar dejo ayer al descubierto un espantoso y horrendo crimen en esta ciudad. El cadáver de una mujer fue arrastrado por la marejada y rescatado frente a la playa de las industrias pesqueras justo donde se ubican los tanques de petróleo en el industrial. El cuerpo sin vida de una mujer de aproximadamente 34 años presentaba una muerte estimada en ocho días de antigüedad.

El cadáver apareció atado con un firme nudo a una cuerda de nylon de color amarillo. El o los homicidas intentaron "fondearla" a la infortunada víctima, a manera de ancla, en el extremo presentaba una pesada "zapata" de ferrocarrilera de las que usan en los convoyes para sus frenos.

Pesado trozo de metal fue encargado de llevar hasta el fondo del océano a la difunta, la que aparentemente reflotó el cuerpo debido a la descomposición, la que actuó como elemento inflable natural [...].

El cuerpo estaba desnudo hasta la cintura, la víctima llevaba solamente un blue jeans y calzón de fibra sintética.

Macabro hallazgo. La occisa estaba irreconocible debido a que presentaba ausencia total de la piel, cuero cabelludo, ojos, y en definitiva cualquier rasgo que permitiera su identificación. Sólo una gargantilla presumiblemente de oro será el elemento 
destacable que a la postre podría servir cómo pista de identificación [...]. Irreconocible. [...] El alto funcionario y sus oficiales se dedicó a cumplir el primer peritaje y examen ocular de la occisa. La tarea de reconocimiento, a primera vista, resulto completamente estéril. El cuerpo de contextura gruesa, de un metro sesenta, aparentemente presentaba sólo lesiones típicas del arrastre en toda la zona cervical. El rostro carecía de ojos, nariz, boca, partes blandas, que fueron devoradas por los peces y constituía sólo una masa blanca e uniforme de carne [...].

Alrededor de su cuello una gargantilla brilló como el elemento que a la postre podría ser la pieza vital en la investigación, tanto como lo será la autopsia que se realizará a primeras horas de hoy $[\ldots]^{28}$.

Las fotografías del cadáver informe de Juana fueron expuestas junto a sus fotografías de bailarina de la bohemia antofagastina, con sus atuendos que dejan ver partes de su cuerpo desnudo y belleza que luego se va a quebrantar con su tortura y muerte. Así las imágenes de la apertura de su cadáver siguen siempre en primer plano, expandiendo la imaginación de los lectores a toda forma de fantasía y ficción antes, durante y después de perpetrado el crimen. Según Didi-Huberman "no existe imagen del cuerpo sin la apertura -el despliegue hasta la herida, hasta la dilaceración- de su propia imaginación” (135). La exposición fotográfica del cadáver de "la prostituta" como deshecho muestra las condiciones para la producción "del horror del caos" (Lynn 31) y sus significantes la apuntan como agente de ese caos, el que se construyó en la circulación de una estética de tentación, de mujer caída, de culpa, de violencia masculinizada, de amenaza, de silenciamiento, de mensaje, de castigo, de vicios, de intimidación, extendido hacia los lectores. En un espectáculo en que el cadáver participa de lo que Jean Clair plantea como "exhibición de una vida desnuda de los órganos, de una fisiología del estado puro, exaltación del residuo biológico, fascinación por la muerte bajo el aspecto de cadáver: no se está lejos de un carnaval, con todo lo que acompaña esta inversión regular, ritual y pasajera de un orden social” (26).

Aquí, entonces, se intentaba revivir el "síntoma recurrente de una figuralidad" del cuerpo muerto contemplado, que según Didi-Huberman exige "una tarea psíquica en la que se desarrolla toda la subjetivación de mundos fantasmáticos” (La venus rajada 41) que se somete a la producción y visibilización del síntoma del cuerpo que figura el horror a través de los elementos secundarios que recogen el pathos de la escena. En las primeras imágenes se muestran estos cadáveres en los lugares donde fueron ocultados-encontrados y al personal policial que los examina y monitorea, lo que nos hace dirigir la mirada hacia el "objeto síquico" al ocultar e indicar aquello que quieren "ignorar nuestros esfuerzos conscientes para discernir y objetivar las cosas del mundo" (104). De este modo se marca aquello a lo que "le volvemos la espalda", la condición de residuo, de ultraje, de descomposición, lo informe. Es en un acto de doblez que, por un lado, nos esconde la supuesta aberración y, por otro, nos obliga o demanda su contemplación, se exhibe en la íntima relación de comunión

28 "Espantoso y horrendo crimen en Antofagasta. Con "zapata de fierro "fondearon" a una mujer". La Estrella del Norte, 22 de febrero 1983: 5 [Antofagasta, Chile]. Medio impreso. 
que se establece en la autoridad del poder soberano. En la manifestación pública de una escatología aceptada y celebrada, según Clair, se plantea como necesidad y condición de la unidad del socius: "Todo ocurre como si, de la exposición de estos cuerpos entregados al horror, otro cuerpo, el cuerpo social, sacase una necesidad y, quizás las condiciones mismas de su cohesión" (25).

\section{La maquinaría de exclusión de los cuerpos-cadáveres de las mujeres asesinadas en Calama y Antofagasta}

La resolución de los crímenes de estas mujeres fue traducido por policías y periodistas como "un rompecabezas" que concluía una vez solucionado el "enigma" de la identificación de víctimas y asesinos. Identificación que suponía dotar de contenido y de sentido a todo el caso a través de la individualización, del cierre de contexto, del acotamiento de los eventos, de las asociaciones entre grupos de personas y lugares. En fin, todo aquello que pone en marcha la maquinaría de inclusión-exclusiva, donde la exhibición de imágenes inicia la operación que va en búsqueda de la individuación como criterio para normar. Entendiendo esta individualización como lo plantea Didi-Huberman, "principium individuationis: un criterio dirigido a fundamentar la “filiación”, es decir el reconocimiento o la asignación de identidad” (75), la cual fue determinada por el contexto socioeconómico que se vivía y entre las clasificaciones disponibles que contaban los agentes de estado en los lugares donde acontecieron los asesinatos.

Los registros de estas mujeres asesinadas comenzaron, entonces, con sus imágenes y las nuevas identificaciones, la mujer de las botas negras" y "la mujer fondeada”, que reflejaban nombres indicativos de cadáver, de residuo, de sexualización y de violencia hacia una y todas las mujeres. Y continuaron ratificándose en el desarrollo de los casos policiales, con las declaraciones y rumores de conocidos y desconocidos sobre sus actividades cotidianas, sus orígenes, sus filiaciones, su género, su estatus, etc. Aunque las características descritas en estos relatos las asimilaban a la vida de cualquier mujer migrante que trabajaba hace algún tiempo en estas ciudades, fueron la sexualización y la violencia asociadas a sus crímenes lo que las clasificaba irrevocablemente al papel designado a las prostitutas en estas ciudades mineras en los momentos en que acontecieron sus asesinatos. Se puede decir que, desde un comienzo, la fotografía y las indagaciones policiales sobre la identidad de la mujer asesinada en el camino de Calama a Chuquicamata, ya era una desaparecida de los lenocinios de la ciudad:

Según versiones policiales la víctima no sería del Departamento del Loa, pues nadie ha podido avanzar nada hasta el momento acerca de su identidad. Por averiguaciones practicadas en varios sectores de Calama, los investigadores creen que podría tratarse de una mujer de vida nocturna ${ }^{29}$.

29 "El cadáver de una desconocida preocupa a la policía del Loa”. El Mercurio de Calama, 9 de septiembre 1969: 2 [Calama, Chile]. Medio Impreso. 
Los sabuesos de investigaciones luego de concentrar sus pesquisas en los centros nocturnos de Calama, lograron establecer que de la boite habían desaparecido dos bailarinas. Sin embargo, estas fueron ubicadas en la boite Manhattan de Arica. También la policía descartaría la posibilidad de que el cadáver [...] correspondía a una prostituta antofagastina. Lo más probable es que el cadáver corresponda a la mujer de un delincuente, la que luego de maltratarla brutalmente, la asesinó ${ }^{30}$.

El proceso de identificación del cadáver de la mujer, encontrada flotando en una playa de Antofagasta, mostró que al tiempo en que se buscaba su identidad, se definía una nueva identidad basada en fotografías de distintos ángulos, su condición de cadáver y en los atuendos que aún portaba. Estas características, junto a las posibilidades de significantes que en ese momento y en ese lugar se disponían por policías, lectores y testigos, definieron las clasificaciones según los cuidados de su cuerpo, la calidad de sus ropas y su colgante, con los cuales se infirió su condición social, origen y actividades en al menos tres tipos de mujeres que podían terminar con este fatal destino: una mujer "decente" víctima que se suicida o "la madre" extraviada, o "una amiga de la noche" de buen status:

Los testigos [...] señalaron además que la mujer parecía poseer una buena situación económica, ya que llevaba una gargantilla de oro en su cuello, de la cual colgaba un pequeño zapato del mismo metal. "Tenía también unas tapaduras de oro en su dentadura y sus manos estaban bien cuidadas, al igual que su ropa, por eso pensamos que no se trataba de una mujer de la calle ${ }^{31}$.

!Era madre!. Otro antecedente confirmado por los investigadores dice relación con el estado de la mujer, cuyo cuerpo presenta una cicatriz producto de una operación cesárea, detalle importante que indica que la desconocida fue madre. También se estudiaron pequeños detalles que hablan del estrato social de la mujer, quien por el sólo cuidado de las uñas y las manos, así como la calidad de sus prendas de vestir -todas nuevas- proviene de un estrato social medio acomodado. Se descarto de plano y desde el comienzo que se tratara de una mujer de "vida ligera"32.

Así lo señalo a este diario el comisario subrogante de Investigaciones de Calama. José Galdamez, quien informó que se está realizando ese peritaje: “es posible que corresponda a una mujer calameña. Hay muchas personas que abandonan el hogar y que después aparecen en extrañas circunstancias y eso es lo que pudo ocurrir en la capital regional [...]. Por otra parte la población calameña se ha sentido profundamente impactada por las circunstancias que rodean la muerte de la mujer y es comentario obligado en todos los lugares de concentración pública. Rodolfo Herrera, quien estaba en la plaza 23 de Marzo [...], señaló: Es algo terrible, las fotos

30 "El misterio envuelve la muerte de la mujer mutilada". La Estrella del Norte, 10 de septiembre 1969: 16 [Antofagasta, Chile]. Medio impreso.

31 “Apasionantes entretelones en torno al hallazgo del cadáver. Revelador testimonio de testigos claves". La Estrella del Norte, 23 de febrero 1983: 6 [Antofagasta, Chile]. Medio Impreso.

32 "Al rojo interrogantes por caso de la mujer fondeada. ¿Quién es la desconocida?, ¿Homicidio?. La pregunta ha quemado los labios a toda la segunda región y el país”. La Estrella de/ Norte, 23 de febrero 1983: 5 [Antofagasta, Chile]. Medio Impreso. 
son impresionantes, un buen golpe periodístico. Yo esestimo que a esta mujer la tuvo que haber matado un pescador; porque de acuerdo a los antecedentes que ustedes entregan, es lo más que se aproxima. La zapata de fierro, las corrientes marinas que trasladaron el cadáver, etc.". La señora Mercedes Colque nos dijo: "hoy compré nuevamente el diario para saber que realmente pasó con esa pobre mujer. Me da la impresión que debe ser del ambiente, a lo mejor porque muchas de ellas abandonan el hogar y no se sabe nada más de ellas [... $]^{33}$.

Tocopilla. Ante la eventual posibilidad que el cadáver encontrado en Antofagasta se trate de una persona de paso por la ciudad y que sus pocas descripciones [...] pudieran pertenecer a alguien de otros puntos de la región, incluso de Tocopilla, como también se dijo, reporteros de éste diario realizaron una investigación -encuesta entre la población y la policía civil. [...]. La Calle. La opinión pública de los pobladores consultados sobre la posibilidad del horrendo crimen o suicidio [...], fue dispar y muchos no se atrevieron a entregar opinión porque "el asunto, dijeron, todavía esta muy oscuro". [...] "Yo le doy mi opinión pero nada de nombres, ni fotografías", nos dijo una señora, "Pienso que fue un crimen. Qué como la mataron eso por supuesto lo determinará la autopsia, per tengo la tincada que se trata de una de estas niñas que trabajan por temporada en negocios nocturnos, en eso de los topless y que se cuidan mucho el cuerpo. Como la mayoría viene del sur, nadie por eso la ha podido identificar." Una versión muy similar tuvo un comerciante quien habló también de que sería "una amiga de la noche”. Cuando el reportero le señala que tenía una cicatriz de cesárea y que si se refería a aquellas mujeres que alegran las noches con sus bailes y desnudos, podría ser que no fuera bailarina. Al responder aclaró, "he leído diario y allí dice que tiene una cicatriz de este tipo, pero le insisto esas mujercitas se mueven de un lado a otro"34.

Sobre esta maquinaria de individualización que incluye y excluye se afirmó toda una arquitectura de identificaciones e imaginarios acerca de estas mujeres, de quienes las rodearon, de quienes podían hablar sobre ellas y de quienes pudieron haberlas asesinado articulando luego sus historias de vida para que formaran parte de sus historias de muertes. Historias que se produjeron a partir de su participación en la bohemia en las ciudades donde fueron asesinadas, de la exposición de imágenes de sus cadáveres informes, de la descripción y repetición de las muertes violentas que tuvieron, donde la muerte marca el comienzo, pero como muertes desnudas o nuda muerte, disponibles como lugar de inscripción, de apropiación y de resignificación.

Las inscripciones fraccionadas de imágenes sobre los confines de lo humano por "sufrimiento" y "victimización" "ensañamiento y perversión” componen sus actuales historias populares y la de sus impunes asesinos. La misma maquinaria de individualización/

33 "En Calama También buscan la pista de La Mujer Fondeada". La Estrella del Norte, 24 de febrero 1983: 6 [Antofagasta, Chile]. Medio impreso.

34 "La occisa podría ser tocopillana". La Estrella del Norte, 24 de febrero 1983: 6 [Antofagasta, Chile]. Medio impreso. 
exclusión que conlleva la identificación y que implicó desconectar, dividir, separar, marginar a personas de intercambios, de lugares y de actividades, se utilizó con los asesinos como animal o no-humano. Desde el inicio se clasificaron como "marginados" y "delincuentes"; luego se transformaron en criaturas y en partes del cuerpo personificadas: "el chacal del Loa”, "feroz depravado”, "homicida sádico", “elemento del tercer sexo”, “manos asesinas”, “sádico mirón” (Ver Figuras 5, 11 y 13). Esta transformación en aquello que puede desfigurar o borrar el rostro de alguien, su identidad, fue descrita como pulsión animal masculinizada que se invisibilizó en el anonimato. Para Agamben, esta “máquina antropológica” funciona "en la medida en que en ella está en juego la producción de lo humano mediante la oposición hombre/animal, humano/inhumano" (Lo abierto 75), lo que termina por borrar estas disociaciones al trasladarlo a los limites de lo permitido, integrándolo a otro espacio, el de la animalidad, una otra cosa que asecha desde afuera, pero que no es posible de atrapar o controlar formando ya parte de la misma víctima y no del perpetrador.

Lo mismo sucede con la prostituta y la santa: no hay disociación, ambas están íntimamente producidas, y se ajustan para indicar la inclusión y la exclusión de la otra. Ahora, la inclusión de la santa prostituta se ubicó en función de un afuera asociado a la animalidad sexual del hombre, la misma sexualidad masculinizada que la excluyó como "animal aislado en el mismo cuerpo humano"( Lo abierto 75), instalando los imaginarios de la prostituta santa. Esta articulación se sustenta en una cierta economía política que por un lado, permite establecer los arreglos necesarios para que "el vicio también tenga sus categorías y privilegios" ${ }^{35}$, y por otro, en las peticiones de milagros para que se puedan cumplir deseos y necesidades quebrantadas, ambas ratificadas por el orden establecido de "las remuneraciones de los mineros". Precisamente fueron esas reglas del juego las que instalan la figura de la prostituta tanto por su subversión, como por el peligro que corre al relacionarse con "personas intocables" ${ }^{36}$ en estas ciudades mineras.

Los arreglos económicos y la afirmación de una masculinidad asociada al trabajo minero desbordada en el "ambiente", ahí donde convivían lo humano y lo animal da inicio a las historias de estas mujeres, las que continúan con sus muertes y su sacralidad en el panteón de figuras religiosas. La historia de Irene comienza con las declaraciones de su conviviente, quien cuenta que la conoció en un prostíbulo en Concepción, y la historia de Juana comienza con sus experiencias en el ambiente y los vicios que la transformaron. En ambas historias, el ambiente y sus riesgos serían los causantes de sus asesinatos, aunque en los dos casos los principales sospechosos fueron sus parejas. Sin contar con las pruebas suficientes, estos asesinatos fueron sobreseídos:

Álvarez (su conviviente) se enamoró de Irene en 1965, la sacó de la prostitución, le proporcionó otra profesión, se la llevó a vivir donde él fuera, pero ella no quiso o no pudo cambiar su forma de vida. Por esa razón y haciendo prevalecer su honor

35 "Las alegres noches y ...sus lacras". EL Mercurio de Calama, 4 de noviembre 1971:2 [Calama, Chile], Medio impreso.

36 "En este caso hay metida gente muy importante...". La Estrella del Norte, 19 de mayo 1983: 5 [Antofagasta, Chile]. Medio Impreso. 
de hombre, Mendoza habría actuado impulsado por el despecho y la venganza ${ }^{37}$. Juana había sido amante de un ex boxeador. Más tarde se instaló con una peluquería. Pero todo parece indicar que su sino la empujaba al ambiente del vicio y del submundo delictual. Por lo que se sabe se vinculó indirectamente con la mafia de la droga, que en Antofagasta y en otros puertos reina sin contra peso. Oscuros detalles perfilan el motivo de su muerte: Venganza de una pandilla engañada por una banda rival en la entrega de un "encargo" valorado en unos seis millones de pesos...La mitad más uno de Antofagasta era sospechosa de haber participado en el crimen,... pero el OS7 de carabineros ya tiene en su poder a los homicidas ${ }^{38}$.

La falta de rostros y cuerpos en estas mujeres asesinadas terminaron por moldear su forma divina. En las solicitudes de favores y en los relatos actuales de sus historias se conocen y condenan a los culpables más nombrados: "dos pacos" en el caso de Irene y "los ratis" en el caso de Juana. Estas acusaciones no dejan de tener sentido porque tanto en los tiempos que fueron asesinadas como hoy, una de las figuras que se relacionan al poder y la influencias como "intocables" son las policías en estas ciudades. En sus altares se les dio el rostro de una de las fotografías de prensa en que aparecen sonriendo, la que se ubica regularmente en el centro de estos. Sin embargo, sus cuerpos siguen siendo mutilados en los relatos descritos por hombres y mujeres, aunque reconociendo que antes de sus asesinatos eran mujeres atractivas y voluptuosas, recobrando su pasado de prostitutas. Así se vuelve nuevamente a reclamar sus cuerpos, pero ahora exaltados, como trasgresores y vulnerables, marginales y distinguidos, asociados a la experiencia y al talento en la conquista y el deseo sexual, a los peligros de la noche, a los cuidados del cuerpo, y de otras materias que se consideran fuera de lo moralmente permitido:

señora d la botitas negra tu fuiste algun dia como yo te pido d todo corazón que me ayudes [...]. Te pido con todo corazon que todas las noches yo bien con los clientes que saque mucho trago de 10mil..." (0894).

Botitas te quiero pedir un gran favor que me des mucha suerte para ni trabajo quiero que todos me busquen a mi ya que los hombres nos han echo mucho daño y me han hecho llorar (0700)39.

Juanita por favor ayudame con que ... no la llame y que ella conoces ha otro hombre, por favor Keme llame, hazlo pensar en mi. K se olvide del resto, K deje de ver a la mujer de alado, te lo pido de todo corazón.

Juanita aquí estoy en tu morada. Te pido que me concedas tu petición, sería que me ayudes a tener mi pareja a mi lado a tener noticias de él. Si no fuera quiero encontrar un verdadero amor, noble y fiel porfavor ${ }^{40}$.

37 "Resuelven crimen de Irene Iturra S.". El Mercurio de Calama, 25 de enero 1971: portada [Antofagasta, Chile]. Medio impreso.

38 “Darán a conocer los nombres de los feroces asesinos". La Estrella de/ Norte, 30 de junio 1983: 8 [Antofagasta, Chile]. Medio impreso.

39 Archivo Cartas Botitas Negras (2006-2008), legajo cartas altar Cementerio Municipal de Calama (Chile).

40 Archivo Cartas Juanita (2010-2011), legajo cartas altar en Avenida Pérez Zucovich Antofagasta (Chile). 


\section{Referencias}

Agamben, Giorgio. Homo Sacer. El poder soberano y la nuda vida. Pre-Textos: Valencia, 1988. Medio impreso.

---. Lo abierto. 2002. Buenos Aires: Adriana Hidalgo Editores, 2006. Medio impreso.

Alvear, Jorge. Chile nuestro cobre. Chuquicamata, El Salvador, Potrerillos, El Teniente, Enami, Mantos Blancos y Andina. Santiago: Editorial Lastra, 1975.

Bähr, Jurgen. "Migraciones en el Norte Grande de Chile. Resultados de un análisis de movimientos migratorios entre los años 1965 y 1970". Revista de Geografía Norte Grande 7 (1980): 3-20. Medio impreso.

Clair, Jean. De Inmundo. Apofatismo y apocatástasis en el arte de hoy. Madrid: Arena Libros, 2007. Medio impreso.

Didi-Huberman, Georges. La Venus rajada. 1999. Losada: Buenos Aires, 2005. Medio impreso.

--- La invención de la histeria. Charcot y la iconografía de la Salpêtriére. 1982. Madrid: Ediciones Cátedra, 2007. Medio impreso.

Certeau, Michel de. La invención de lo cotidiano. México: Universidad Iberoamericana, 1996. Medio impreso.

Manning, Alice Elizabeth. Calama: Patterns of Interaction in a Chilean City. Tesis doctoral en Antropología Cultural. Universidad de Columbia, 1975. Medio impreso.

Menard, Andrés. "Pudor y representación. La Raza mapuche, la desnudez y el disfraz". Aisthesis 46 (2009): 15-38. Medio impreso.

Nead, Lynn. "The Magdalen in Modern Times: The Mythology of the Fallen Women in PreRaphaelite Painting”. Oxford Art Journal 7.1 (1984): 26-37. Medio impreso.

Oyarzún, Kemy. "Desnaturalizar las diferencias: sexo, cultura, poder". Escrituras de la diferencia sexual. Ed. Raquel Olea. Santiago: LOM / La Morada, 2000. 267-284. Medio impreso.

Pavez Jorge y Lilith Kraushaar, "Nombre, muerte y santificación de una prostituta. Escritura y culto de Botitas Negras", AlBR Revista de Antropología Iberoamericana 5 (3): 447-492, 2010. Medio Impreso.

Rojas, Jorge y Gonzalo Rojas. “Auditores, lectores, televidentes y espectadores. Chile Mediatizado. 1973-1990”. Historia de Vida privada en Chile. El Chile contemporáneo de 1925 a nuestros días. Dir. Rafael Sagredo y Cristian Gazmuri. Tomo III. Santiago: Aguilar Chilena de Ediciones, 2007. Medio impreso.

Vilches, Lorenzo. Teoría de la imagen periodística. Barcelona: Paidós, 1987. Medio impreso.

Walkowitz, Judith. La ciudad de las pasiones terribles. Narraciones sobre el peligro sexual en el Londres victoriano. Madrid: Ediciones Cátedra, 1992. Medio impreso.

Recibido: 12 diciembre 2012 Aceptado: 1 abril 2013 